Indonesian Journal of Islamic Psychology

Volume 1. Number 2, December 2019. p-ISSN 2685-1482, e-ISSN 2714-7576

website: http://e-journal.iainsalatiga.ac.id/index.php/ijip/index

\title{
Pengaruh Iri Hati Terhadap Munculnya Schadenfreude
}

\section{Aufa Abdillah ${ }^{*}$}

Institut Agama Islam Negeri Salatiga, Indonesia

\begin{abstract}
Schadenfreude is a compound word of the word Schaden, which means loss, and Freude, which means joy. It shows that envy plays an important role in generating Schadenfreude; People are pleased with the misfortune of others when this misfortune gives them a social comparison that increases the feeling of their selfesteem or removes the basic feelingof hurtful jealousy. This research method is experiments with factorial design. The Sampling techniques uses Random Sampling. Analysis techniques are used with the correlation technique of Pearson Product moment. The results of this study complement these opposing findings, indicating that envy is the Schadenfreude predictor when the target has the same gender. This research was conducted at one of the universities in Salatiga.
\end{abstract}

Keywords: Schadenfreude; other's sorroe; envy.

\begin{abstract}
Abstrak
Schadenfreude adalah kata majemuk dari kata Schaden, yang berarti kerugian, dan Freude, yang berarti sukacita. Hal tersebut menunjukkan bahwa iri hati memainkan peran penting dalam membangkitkan Schadenfreude; orang merasa senang dengan ketidakberuntungan orang lain ketika ketidakberuntungan ini memberi mereka perbandingan sosial yang meningkatkan perasaan harga diri mereka atau menghilangkan dasar perasaan iri hati yang menyakitkan. Metode penelitian dengan eksperimen dengan desain faktorial. Tehnik pengambilan sampel menggunakan Random Sampling. Teknik analisis data yang digunakan dengan tehnik korelasi Pearson Product Momen. Hasil penelitian ini melengkapi temuan-temuan yang berlawanan ini, dengan menunjukkan bahwa iri hati adalah prediktor Schadenfreude ketika targetnya memliki gender yang sama. Penelitian ini dilakukan di salah satu universitas di Salatiga.
\end{abstract}

Kata Kunci: Schadenfreude; kemalangan orang lain; iri hati. 


\section{Pendahuluan}

Schadenfreude adalah kata majemuk dari kata Jerman Schaden, yang berarti kerugian, dan Freude, yang berarti sukacita, dan digunakan saat ini sebagai kata pinjaman dalam bahasa Inggris. Pada tahun 1895, Oxford English Dictionary (OED) memasukkan Schadenfreude untuk pertama kalinya sebagai entri dan mendefinisikannya hingga saat ini sebagai "kenikmatan jahat atas kemalangan orang lain. Schadenfreude dapat dikategorikan sebagai jenis kesenangan, tetapi jenis kesenangan yang tidak khas. Sedangkan kesenangan dalam hal ini lebih mengacu pada situasi di mana orang senang ketika orang lain tertimpa kemalangan (Ortony, Clore, \& Collins, 1988). Tetapi schadenfreude mungkin bukan jenis kesenangan yang tidak lazim meskipun tidak sesederhana kelihatannya. Hal ini dapat dijelaskan berdasarkan teori appraisal (Appraisall Theory), yaitu teori dalam psikologi yang menyatakan bahwa emosi diekstraksi dari evaluasi individu terhadap peristiwa yang menyebabkan reaksi spesifik pada orang yang berbeda. Pada dasarnya, penilaian individu terhadap suatu situasi menyebabkan respons emosional, atau afektif, yang akan didasarkan pada penilaian itu (Roseman \& Smith, 2001).

Berdasarkan penjelasan Emotional Evaluation Theory (teori penilaian emosi) bahwa mengapa peristiwa yang sama dapat membangkitkan emosi yang berbeda pada orang yang berbeda, yaitu karena mereka menilai situasi yang sama secara berbeda, atau mengapa peristiwa yang berbeda dapat membangkitkan emosi yang sama dalam diri seseorang yaitu, karena seseorang menilai situasi yang berbeda dengan cara yang sama. Sebagai contoh, kemalangan orang lain dapat membangkitkan simpati pada beberapa orang dan schadenfreude pada orang lain karena mereka berbeda dalam hal penilaian kemalangan. 
Aufa Abdillah

Penilaian terhadap suatu peristiwa lebih daripada peristiwa itu sendiri yang terus-menerus memunculkan emosi, schadenfreude dapat ditimbulkan oleh sejumlah peristiwa yang tidak terbatas, di antaranya adalah karena iri hati (Roseman \& Smith, 2001). Dengan demikian, karena penilaian atas kemalangan orang lain lebih daripada kemalangan itu sendiri yang membangkitkan Schadenfreude, maka munculnya schadenfreude tidak memerlukan karakter umum yang konkret. Peristiwa obyektif yang berbeda, misalkan seorang teman yang didengki mematahkan tumit sepatu barunya yang indah, seorang rekan sombong yang ditolak promosi, seorang yang tidak berbakat menjadi bintang yang banyak dikritik, kemungkinan semuanya membangkitkan schadenfreude jika kemalangan ini dinilai dengan cara yang sama.

Shcadenfreude muncul karena emosi negatif ditimbulkan oleh peristiwa yang membahayakan atau mengancam kekhawatiran individu, sedangkan emosi positif ditimbulkan oleh peristiwa yang memuaskan kekhawatiran ini. Dengan demikian, hal yang membangkitkan schadenfreude, kemalangan orang lain harus dinilai oleh schadenfroh (orang yang gembira dengan kemalangan orang lain) sebagai hal yang memuaskan beberapa masalah pribadi yang penting. Dengan kata lain, sesuatu tentang kemalangan orang lain harus bermanfaat bagi orang yang mengalami schadenfreude (schadenfreude adalah perasaan senang sedangkan schadenfroch adalah pelakunya). Jadi, kemalangan seorang teman yang didengki, dapat membangkitkan schadenfreude jika kemalangan ini memberi manfaat psikologis bagi schadenfroch.

Ketika kemalangan menimpa orang lain, reaksi seseorang dapat bermacam-macam. seseorang dapat bersimpati dan memiliki perasaan prihatin serta berduka terhadap yang lain (Eisenberg, 2000), tetapi juga dapat mengalami Schadenfreude, reaksi emosional yang didefinisikan 
sebagai menikmati kesenangan dalam kemalangan orang lain (Heider, 1958). Reaksi emosional yang terakhir ini telah dikaitkan dengan iri hati oleh banyak sarjana (Elster, 1989; Heider, 1958; Mora, 1987; Plato 427348 SM / 1925; Spinoza, 1677/2002). Iri hati ini sangat umum juga diistilahkan dengan kedengkian (Envy). Meskipun catatan teoritis tentang hubungan antara iri hati dan schadenfreude berasal dari para filsuf Yunani kuno seperti Socrates dan Plato, dukungan empiris untuk tautan teoretis yang diajukan harus menunggu sampai akhir 1990-an, ketika Smith dan rekannya secara eksperimen menunjukkan bahwa schadenfreude muncul ketika orang yang didengki mengalami kemalangan (Brigham, Kelso, Jackson, \& Smith, 1997; Smith, Turner, Garonzik, Leach, Urch-Druskat, \& Weston, 1996). Namun, penelitian terbaru menantang temuan dengan gagal mendokumentasikan hubungan antara iri hati dan Schadenfreude (Feather \& Sherman, 2002; Hareli \& Weiner, 2002). Dalam penelitian ini diusulkan bahwa hasil yang bertentangan ini dapat direkonsiliasi dengan menunjuk pada kondisi spesifik di mana iri hati dapat memprediksi dan tidak memprediksi schadenfreude.

\section{Dasar Hubungan iri Hati dan Schadenfreude}

Iri hati (kedengkian) timbul ketika seseorang tidak memiliki kualitas, prestasi, atau kepemilikan yang superior dari orang lain dan menginginkannya atau berharap orang lain tidak memilikinya (Parrot \& Smith, 1993). Biasanya diiringi emosi sebagai reaksi psikologi yang sangat tidak menyenangkan, yang mencakup perasaan rendah diri, permusuhan, rasa ketidakadilan, dan rasa ke-berhak-kan atau deservness (Parrot, 1991; Smith, 1991). Kemalangan yang menimpa orang lain yang didengki akan mengurangi rasa kedengkian. Selain itu, dapat 
mengurangi tingkat perbandingandan itu sehingga memberikan keuntungan yang sifatnya relativ bagi pelaku iri hati (Ortony, Clore, \& Collins, 1988; Smith, 2000; Smith et al., 1996). Smith dan rekannya memberikan dukungan empiris tentang adanya hubungan antara iri hati dan Schaenfreude (Brigham et al., 1997; Smith et al., 1996). Dalam studi ini, para partisipan lebih senang ketika mengetahui orang yang didengki tertimpa kemalangan daripada ketidakberuntungan. Orang tersebut mengatakan bahwa efek ini pada Schadenfreude dimediasi oleh rasa iri hati para peserta terhadap target.

Namun, studi empiris yang lebih baru menantang pandangan bahwa iri memprediksi Schadenfreude. Hareli dan Weiner (2002) misalnya, menemukan hubungan yang reliabel dan kuat antara perasaan bermusuhan (yaitu, kemarahan dan kebencian) dan schadenfreude, tetapi gagal untuk mendokumentasikan hubungan antara iri hati dan schadenfreude. Selanjutnya, Feather dan Shenrman (2002) menemukan bahwa schadenfreude didorong oleh kebencian, tetapi tidak oleh iri hati. Dengan demikian, keadaan empiris saat ini membuat para sarjana memiliki pandangan yang bertentangan tentang hubungan antara iri hati (kedengkian) dan schadenfreude. Melihat lebih detail pada studi sebelumnya dapat memberi sedikit lebih banyak pencerahan pada hasil yang bertentangan ini. 
Aufa Abdillah

Mengkaji lebih dekat pada studi sebelumnya tentang iri hati dan

Schadenfreude

Pengujian lebih dekat terhadap studi sebelumnya tentang iri hati dan schadenfreude mengungkapkan bahwa studi ini berbeda dalam beberapa aspek penting. Dua perbedaan penting antara penelitian yang mendukung hubungan antara kedengkian (iri hati) dan Schadenfreude (Brigham et al., 1997; Smith et al., 1996) dan yang tidak berkaitan dengan assesmen iri hati (assessment of envy) serta target yang dihadapkan kepada para peserta (Feather \& Sherman, 2002; Hareli \& Weiner, 2002). Pada bagian berikut ini akan diuraikan bagaimana perbedaan antara studi ini dapat membantu menjelaskan hasil yang bertentangan.

\section{Assesmen iri hati (Envy)}

Penelitian sebelumnya tentang iri hati dan schadenfreude sangat berbeda dalam assessmen iri hati penelitian saat ini. Dalam studi-studi yang mendukung hubungan antara iri hati dan schadenfreude, baik aspek iri hati positif (benign envy) maupun iri hati negatif (hostile envy) juga dinilai. Sedangkan dalam studi-studi yang tidak mendukung hubungan antara iri hati dan schadenfreude hanya menilai aspek iri hati positif. Dalam studi-studi terakhir ini, iri hati secara eksplisit diukur dalam istilah-istilah yang tidak terlalu mengacu pada permusuhan, karena hal tersebut diperdebatkan apakah aspek-aspek yang bermusuhan mendefinisikan ciri-ciri iri hati. Baik Feather \& Sherman (2002) dan Hareli \& Weiner (2002) berpendapat bahwa perasaan bermusuhan (seperti tidak suka dan dendam) tidak dapat menunjukkan karakteristik iri hati dan harus diberlakukan sebagai prediktor independen Schadenfreude. 
Gagasan bahwa perasaan bermusuhan dapat menentukan taraf schadenfreude telah dikemukakan oleh banyak peneliti (misalnya, Ben Ze'ev, 2000; Feather, 1994; Heider, 1958; Leach, Spears, Branscombe, \& Doosje, 2003; Ortony, Clore , \& Collins, 1988; Spinoza, 1677/2002) dan telah menerima dukungan empiris yang cukup besar (misalnya, Brighametal., 1997; Feather, 1989; Feather \& Sherman, 2002; Hareli \& Weiner, 2002; Smith et al., 1996; van Dijk, Ouwerkerk, Goslinga, \& Nieweg, 2005). Dalam pandangan peneliti saat ini, iri hati tidak termasuk komponen permusuhan. Permusuhan ini mungkin merupakan respons psikologi yang bersifat defensif terhadap perbandingan sosial yang tidak menarik atau respons kemarahan terhadap rasa ketidakadilan (yaitu, diyakini bahwa keberuntungan yang dimiliki orang yang didengki itu tidak adil).

Tanpa membahas ciri-ciri spesifik dari pengalaman iri hati secara mendetail, poin yang ingin disampaikan di sini adalah bahwa dalam penelitian-penelitian yang menemukan hubungan antara iri hati dan schadenfreude, penilaian iri hati mencakup perasaan permusuhan, sedangkan ini tidak ditemukan pada studi yang tentang hubungan antara iri hati positif (benign envy) dan schadenfreude. Orang bisa berargumen bahwa perasaan-perasaan bermusuhan itu adalah yang dimaksud oleh Smith dan rekan-rekannya (Brigham et al, 1997; Smith et al, 2000). Dalam assesmen kedengkian (iri hati) mereka, ditemukan hasil bahwa iri hati negatif (hostyle envy) memunculkan schadenfreude. Dengan kata lain, iri hati memprediksi schadenfreude jika perasaan permusuhan dimasukkan dalam assesmen kedengkian (iri hati), sedangkan iri hati tidak memprediksi Schadenfreude jika perasaan permusuhan tidak dimasukkan dalam assesmen. 


\section{Target Schadenfreude}

Studi sebelumnya tentang iri hati dan schadenfreude juga berbeda sehubungan dengan reaksi peserta terhadap target. Dalam studi yang mendukung hubungan antara iri hati dan schadenfreude, sebagian besar peserta bereaksi terhadap target dengan jenis kelamin yang sama dengan mereka. Sedangkan dalam studi-studi yang tidak mendukung hubungan antara iri dan schadenfreude, sebagian besar peserta bereaksi terhadap target dengan jenis kelamin yang berbeda. Lebih khusus, dalam studi pendukung, sebagian besar peserta adalah laki-laki (Smith et al., 1996: 56\%, 64 dari 114) atau hanya laki-laki (Brigham et al., 1997: 100\%, 151 dari 151), yang dihadapkan pada kondisi kemalangan yang dihadapi target laki-laki saja. Sebaliknya, dalam studi yang tidak mendukung temuan hubungan iri hati dan Schadenfruede sebagian besar peserta adalah perempuan (Feather \& Sherman, 2002: 74\%, 136 dari 183; Hareli \& Weiner, 2002, Studi 2: 70\%, 35 dari 50; Hareli \& Weiner, Studi 3: 70\%, 86 dari 123), yang dihadapkan dengan kondisi kemalangan salah satu target wanita atau pria (Hareli \& Weiner, 2002, Studi 2). Atau kondisi kemalangan pada target laki-laki saja (Hareli \& Weiner, 2002, Studi 3). Atau kemalangan/ketidakberuntungan pada target dengan gender yang tidak sesifik (Feather \& Sherman, 2002). Ini memunculkan kemungkinan bahwa dukungan untuk hubungan antara iri hati dan Schadenfreude mungkin tergantung pada tingkat kesamaan antara peserta dan target.

Bagian dari kesenangan dalam schadenfreude berasal dari transformasi perbandingan yang tidak jelas menjadi perbandingan yang lebih menguntungkan, yang menyoroti kelebihan diri sendiri daripada kerugian. Transisi ini memberikan peluang mudah untuk peningkatan diri (Self-Enhancement) dan mungkin sangat menyenangkan ketika 
perbandingan sosial secara langsung relevan dengan diri dan tujuan pribadi seseorang (Smith, 2000). Model Self-Evaluation Maintenance (SEM) Tesser (Tesser, 1991) mengemukakan bahwa reaksi psikologis terhadap informasi perbandingan sosial tergantung pada perbandingan kinerja orang lain, relevansi domain kinerja dengan definisi diri seseorang, dan kedekatan hubungan dengan orang yang dibandingkan.

Model perilaku evaluasi diri (SEM) difokuskan pada bagaimana kinerja orang lain memengaruhi persepsi dan evaluasi diri baik secara positif maupun negatif. Orang menggunakan kemuliaan yang dipantulkan dari orang lain untuk mendukung citra mereka. Misalkan, Ini terjadi ketika seseorang merasa bangga ketika tim Fahmil Qur'an (cerdas cermat Al Qur'an) almamaternya memenangkan pertandingan besar atau anak mereka memenangkan penghargaan dalam lomba MTQ. Evaluasi diri juga terjadi melalui perbandingan diri sendiri dengan orang lain. Harga diri diperoleh dengan melakukan lebih baik daripada orang lain. Model SEM juga mengidentifikasi variabel yang dapat mempengaruhi apakah efeknya akan positif atau negatif terhadap persepsi diri.

Dua variabel penting dan terkait adalah kedekatan dengan orang yang dibandingkan sendiri dan relevansi tindakan itu sendiri. Jika seseorang membandingkan dirinya dengan seseorang yang sangat dekat dengannya pada faktor yang tidak penting bagi konsep dirinya, maka itu baik untuk harga diri. Misalnya, jika teman si A memenangkan penghargaan besar untuk seni kaligrafi Al Qura'an dan si A tidak kompetitif dalam seni kaligrafi Al Qura'an itu maka itu akan meningkatkan harga dirinya. Jika si A memiliki hubungan dekat dengan seseorang yang memiliki minat pada faktor-faktor serupa, maka kemungkinan besar harga diri si A akan menderita jika mereka 
berperforma lebih baik daripada si A. Dengan mengikuti alur penalaran ini, dapat ditarik argumen bahwa kemalangan yang terjadi pada orang lain yang dekat, yang mengungguli diri sendiri pada domain yang relevan, akan lebih menyenangkan daripada kemalangan yang terjadi pada orang lain yang tidak terlalu berkinerja lebih baik.

Kedekatan didefinisikan di sini dalam arti unit-relasi, mengacu pada hubungan yang ada antara orang-orang yang "dianggap sebagai milik bersama secara khusus dekat" (Heider, 1958). Orang dianggap sebagai milik bersama jika mereka dapat dimasukkan oleh beberapa konstruksi sosial dan penelitian telah menunjukkan bahwa hanya tingkat kesamaan minimal antara dua orang (misalnya, berbagi ulang tahun) diperlukan untuk menciptakan rasa "memiliki bersama" (Miller, Downs \& Prentice, 1998). Selain itu, penelitian telah menunjukkan bahwa kemungkinan perbandingan yang dibuat dan dampaknya terhadap diri tergantung pada kesamaan yang dirasakan antara seseorang dan perbandingan lainnya. Perbandingan sosial yang melibatkan orang yang serupa lebih mungkin dan memiliki dampak lebih besar daripada perbandingan sosial yang melibatkan orang yang kurang serupa (Gastorf \& Suls, 1978; Goethals \& Darley, 1977; Lockwood \& Kunda, 1997; Mayor, Testa, \& Bylsma, 1991; Miller, Turnbull, \& McFarland, 1988; Tesser, 1991; Wood, 1989). Salah konstruksi sosial yang mungkin berfungsi sebagai dasar penting untuk kesamaan adalah gender (contoh lain mungkin kebangsaan, agama, status sosial, keanggotaan keluarga, dll.). Memang, penelitian telah menyarankan bahwa orang memiliki preferensi untuk perbandingan sesama jenis (Major, 1994). Hal ini menunjukkan bahwa iri hati dapat memprediksi schadenfreude ketika ketidakberuntungan atau kemalangan terjadi pada seseorang dengan jenis kelamin yang sama (yaitu, perbandingan serupa lainnya), 
sedangkan iri hati tidak akan memprediksi schadenfreude ketika kemalangan terjadi pada seseorang dengan jenis kelamin yang berbeda (yaitu, perbandingan berbeda lainnya).

\section{Penelitian Sekarang}

Dalam penelitian ini diuji apakah hasil yang bertentangan dari penelitian sebelumnya mengenai hubungan antara iri hati atau kedengkian dan schadenfreude dapat dikaitkan dengan perbedaan dalam: (a). Assesmen atau penilaian iri hati, yaitu, dimasukkan atau tidaknya perasaan permusuhan dalam penilaian iri hati dan atau (b). Kesamaan antara jenis kelamin peserta dan jenis kelamin target. Masalah pertama dibahas dengan menilai perasaan iri hati dan permusuhan secara independen dari satu sama lain. Ini memungkinkan peneliti untuk menyelidiki kontribusi individu dari kedua reaksi psikologis dalam memunculkan schadenfreude. Jika iri hati tidak memprediksi Schadenfreude baik diiringi dan tidak diiringi perasaan bermusuhan, hasil yang bertentangan dari penelitian sebelumnya dapat dikaitkan dengan penilaian iri hati (assessment of envy) yang berbeda. Masalah kedua dibahas dengan memasukkan peserta dan target dari kedua gender dalam penelitian ini. Ini memungkinkan peneliti untuk menyelidiki apakah kesamaan antara jenis kelamin peserta dan jenis kelamin target memiliki pengaruh pada hubungan antara iri hati dan Schadenfreude. Jika iri hati memang memprediksi schadenfreude ketika peserta dan target memiliki jenis kelamin yang sama, tetapi tidak memprediksi schadenfreude ketika mereka memiliki jenis kelamin yang berbeda, hasil yang bertentangan dari penelitian sebelumnya dapat dikaitkan dengan (kurangnya) kesamaan ini. 
Metode Penelitian

Desain dan Partisipan

Partisipan adalah 250 siswa (148 wanita, 102 pria) dari salah satu universitas di Salatiga. Usia rata-rata sampel adalah 20,45 tahun (SD 2,32 tahun). Peserta secara acak ditugaskan ke salah satu dari delapan kondisi dari 2 (Target Prestasi: tinggi vs rata-rata) 2 (Target Gender: pria vs wanita) 2 (Kemalangan: investigasi kriminal vs kinerja akademis yang buruk) dengan desain faktorial. masing-masing dari delapan syarat 2934 peserta ambil bagian. Mereka dibayar Rp. 20.000 sebagai imbalan atas partisipasi mereka.

\section{Prosedur Eksperimen}

Peserta diundang ke laboratorium untuk berpartisipasi dalam studi tentang dampak berbagai media pada pembentukan tayangan. Hingga tiba, mereka dibawa ke bilik terpisah yang berisi komputer, yang digunakan untuk menyajikan instruksi dan informasi stimulus dan untuk mengumpulkan data. Peserta diberitahu bahwa mereka akan membaca dua wawancara di layar komputer mereka, yang merupakan bagian dari serangkaian wawancara yang disebut "Belajar di abad ke-21" dan diduga dikumpulkan dan bekerja sama dengan salah satu universitas di Salatiga. Selanjutnya mereka diberitahu bahwa wawancara ini menyangkut mahasiswa yang akan menyelesaikan studi mereka. Dalam wawancara pertama seorang mahasiswa diwawancarai dan memberikan informasi tentang apa yang dia lakukan di universitas.

Dalam wawancara ini prestasi mahasiswa dan jenis kelamin keduanya bervariasi. Dalam kondisi prestasi tinggi, rincian dibuat untuk membuat mahasiswa tampak luar biasa dalam hal prestasi akademik, keorganisasian, tugas perkuliahan dan kemungkinan mendapatkan 
pekerjaan yang baik. Dalam rata-rata pencapaian, rincian kondisi dibuat untuk membuat siswa tampak rata-rata dalam istilah-istilah ini. Dalam kondisi target pria, mahasiswi dipanggil Solikah. Dalam kondisi target perempuan mahasiswa dipanggil Solikh. Setelah membaca wawancara pertama, peserta diminta untuk menanggapi pernyataan yang berkaitan dengan kesan mereka terhadap mahasiswa, dan beberapa pertanyaan yang dirancang khusus untuk memperkuat klaim yang dibuat dalam instruksi bahwa penelitian ini berkaitan dengan pembentukan kesan dan penggunaan berbagai jenis media.

Setelah pertanyaan-pertanyaan ini, peserta membaca wawancara kedua, yang diduga sebagai pengawas pengawas. Wawancara kedua ini memberi tahu peserta bahwa mahasiswa telah mengalami kemunduran baru-baru ini. Pengawas mahasiswa mengatakan bahwa mahasiswa tersebut tertangkap mencuri laptop dari universitas dan bahwa ia menjadi subjek investigasi kriminal atau bahwa siswa tersebut memberikan presentasi makalahnya yang sangat buruk dan harus menulis ulang sebagian besar dari itu. Dalam kedua kasus mahasiswa mengalami keterlambatan dalam studinya. Akhirnya, setelah wawancara kedua, peserta ditanyai pertanyaan mengenai reaksi mereka terhadap ketidakberuntungan yang terjadi pada mahasiswa.

\section{Iri Hati, Rasa Permusuhan, dan Shadenfreude}

Setelah membaca wawancara dengan mahasiswa, perasaan iri hati dan permusuhan terhadap mahasiswa dinilai. Iri hati dinilai dengan skor rata-rata pada empat pernyataan berikut (Cronbach's .81): "Saya ingin berada di posisi [. . .], "" Aku iri dengan [. . .], "" Saya ingin berada di situasi [. . .], "Dan" Saya merasa kurang enak ketika membandingkan hasil sendiri dengan hasil [. . .]. " Perasaan bermusuhan dinilai dengan skor rata-rata 
pada tiga pernyataan berikut $(0,84): "$ Aku benci [. . .], "' Saya memiliki perasaan jijik terhadap [. . .], "Dan" Saya tidak suka [. . .]. "Setelah membaca wawancara dengan pengawas siswa, peserta Schadenfreude dinilai dengan skor rata-rata pada lima pernyataan berikut $(0,82):$ Apa yang terjadi memberi saya kepuasan, "' Saya suka apa yang terjadi pada [. . .], "' Aku tidak bisa menahan diri untuk tersenyum sedikit, "" Sebenarnya aku ingin tertawa sedikit, "dan" Aku merasa puas dia tidak beruntung. "Semua pernyataan dinilai pada skala 7 poin (1 sangat tidak setuju; 7 sangat setuju) dan disajikan bersama dengan beberapa pernyataan pengisi tentang berbagai aspek target dan kemalangan.

\section{Hasil}

Untuk menyelidiki apakah (a) iri hati memprediksi Schadenfreude diiringi atau tidak diiringi perasaan bermusuhan dan (b) hubungan antara iri hati dan Schadenfreude tergantung pada kesamaan antara jenis kelamin peserta dan jenis kelamin target, analisis regresi hirarki dilakukan pada Schadenfreude. Envy, perasaan bermusuhan, jenis kelamin peserta, dan jenis kelamin target dimasukkan pada langkah pertama dan model yang dihasilkan menjelaskan $17 \%$ dari varians dalam Schadenfreude, $F(4,248)=13.23, p<.001$. Baik rasa iri hati $(\beta=$ $.12, \mathrm{t}[244]=2.08, p<.05)$ dan perasaan bermusuhan $(\beta=36, \mathrm{t}[244]=$ $6.26, p<.001$ ) secara positif terkait dengan Schadenfreude, menunjukkan bahwa Schadenfreude lebih kuat ketika rasa iri hati lebih kuat dan bahwa Schadenfreude lebih kuat ketika perasaan bermusuhan lebih kuat. Selanjutnya, hubungan yang signifikan ditemukan antara jenis kelamin peserta dan Schadenfreude $(\beta=-.12, \mathrm{t}$ [244] $=-2.07, p<.05)$, menunjukkan bahwa Schadenfreude lebih kuat untuk peserta laki-laki daripada peserta perempuan. Selanjutnya, tiga interaksi dua arah antara 
jenis kelamin peserta, jenis kelamin target, dan iri hati dimasukkan $\left(\mathrm{R}^{2} \mathrm{ch}\right.$ $=.02), F(3,241)=2.17, p<.10$. Hasil menunjukkan bahwa hanya interaksi Target Peserta Gender yang memiliki hubungan yang signifikan dengan Schadenfreude $(\beta=.14, \mathrm{t}[241]=2.35, p<.05)$; Schadenfreude lebih intens ketika jenis kelamin peserta dan jenis kelamin target sama. Akhirnya, pada Langkah 3, interaksi Partisipan Gender X Target Gender $\mathrm{X}$ Iri Hati dimasukkan $\left(\mathrm{R}^{2} \mathrm{ch}=.02\right), F(1,240)=5.07, p$.05. Hasil menunjukkan bahwa interaksi tiga arah ini signifikan $(\beta=.13, t[240]=$ 2,25, $p<.05$ ). Mengikuti Aiken dan West (1991), peneliti menentukan kemiringan regresi untuk empat kombinasi berbeda dari jenis kelamin peserta dan jenis kelamin sasaran secara terpisah. Hasil penelitian menunjukkan bahwa iri hati memprediksikan Schadenfreude ketika salah satu peserta laki-laki mempelajari tentang kemalangan dari target laki-laki $(\beta=.13, t[51]=2,30, p<.05)$ atau ketika seorang peserta perempuan mempelajari tentang kemalangan dari target perempuan ( $\beta$ $=.12, t[74]=2.03, p<.05)$. Sebaliknya, iri hati tidak memprediksi Schadenfreude ketika seorang partisipan pria belajar tentang kemalangan target wanita $(\beta=-.04, \mathrm{t}<1$, ns.) Atau ketika partisipan wanita mempelajari tentang kemalangan target pria $(\beta=.02, t<1$, ns; lihat Gambar 1). 


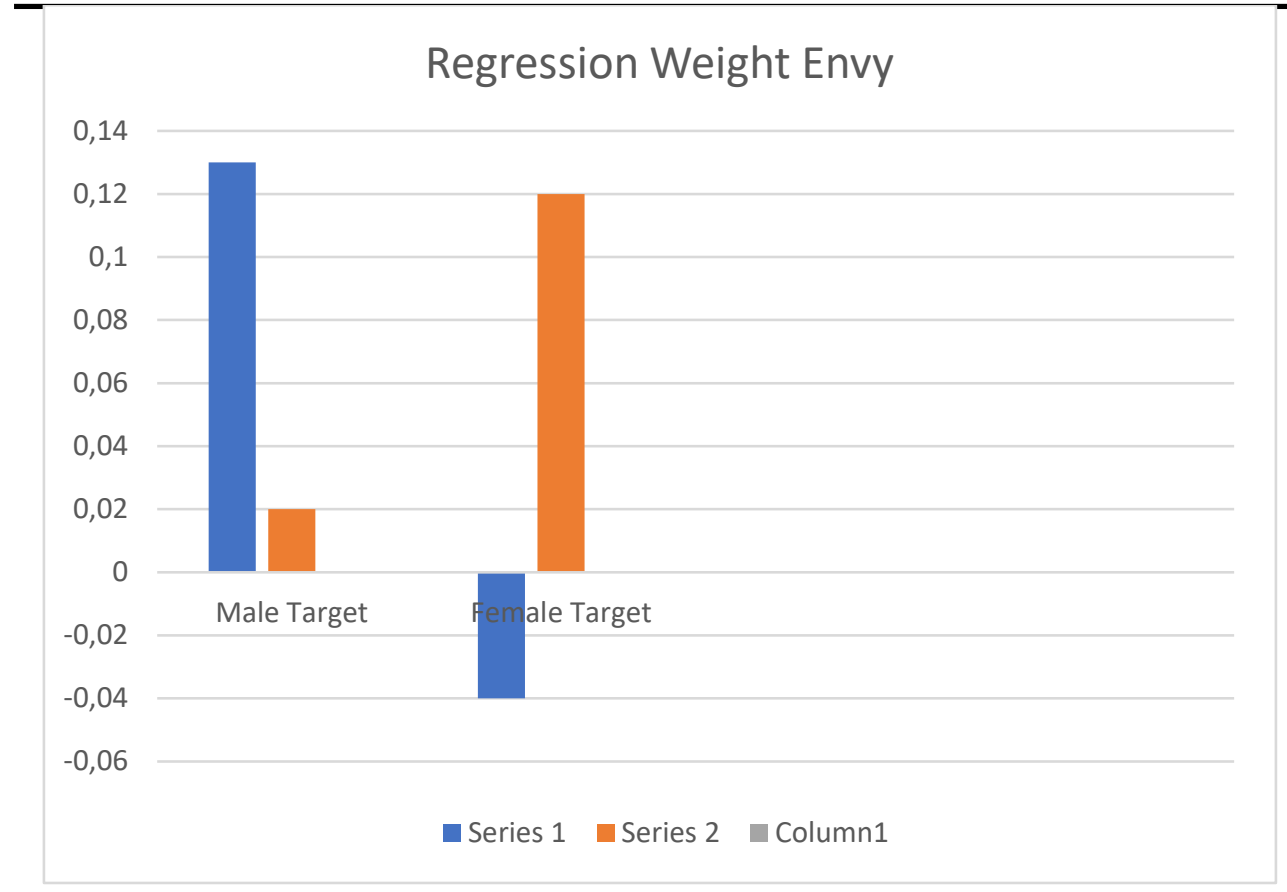

Gambar 1. Bobot regresi iri hati sebagai prediktor untuk Schadenfreude terhadap target pria dan wanita dalam kaitannya dengan jenis kelamin peserta.

Studi ini kembali menemukan bahwa iri hati adalah anteseden dari Schadenfreude. Penelitian ini sesuai dengan temuan hasil penelitian sebelumnya yang melibatkan bahwa rasa kelayakan sebagai anteseden penting Schadenfreude (Feather \& Nairn, 2005; Feather \& Sherman, 2002; Van Dijk et al., 2005, 2009). Yang sangat penting, kami menambahkan temuan ini dengan menunjukkan bahwa manipulasi kelayakankarunia yang dimiliki orang lain memengaruhi rasa Schadenfreude, dan bahwa efek ini (sebagian) dimediasi oleh iri hati.

Ketika membandingkan penelitian sebelumnya yang menghasilkan temuan yang kontras pada hubungan antara iri hati dan Schadenfreude, dapat dilihat bahwa konseptualisasi kedengkian juga bervariasi. 
Penelitian yang menghasilkan hubungan antara kedengkian dan Schadenfreude biasanya menggunakan lebih banyak pertanyaan terkait permusuhan sebagai ukuran kecemburuan, sementara penelitian menemukan tidak ada hubungan seperti itu biasanya menggunakan lebih banyak pertanyaan terkait keinginan atau pertanyaan iri hati yang lebih umum (lihat Van Dijk et al., 2006). Perbedaan ini konsisten dengan pandangan peneliti tentang perbedaan antara iri hati positif (dalam istilah arab ghibthoh) dan iri hati negatif (dalam istilah arab Hasud). Penelitian sebelumnya telah menunjukkan bahwa kedua jenis iri hati memiliki banyak karakteristik penting-baik sebagai hasil dari perbandingan sosial ke atas (upward social comparison) dalam domain yang penting bagi diri sendiri (Fiske, 2011; Miceli \& Castelfranchi, 2007; Smith \& Kim, 2007), tetapi juga telah menunjukkan bahwa iri hati mengarah pada motivasi konstruktif dan destruktif (Crusius \& Mussweiler, 2012; Schaubroeck \& Lam, 2004; Van de Ven et al., 2009). Hal Ini juga menjelaskan mengapa ada kepuasan jahat atas kemalangan yang menimpa orang lain yang didengki, tetapi kedengkian dalam konteks iri hati negatif (malicous envy atau hasud), karena tujuan motivasi iri hati jahat adalah menyakiti posisi yang lain untuk mencegah yang lain menjadi lebih baik. Jika kemalangan menimpa atasan lain tujuan motivasi ini puas, memicu perasaan positif (Schadenfreude). Dengan demikian, dengan menguhi apakah iri hati berbahaya, berkaitan dengan Schadenfreude, peneliti berkontribusi untuk mengintegrasikan dan menjelaskan temuan kontradiktif sebelumnya.

Temuan saat ini menunjukkan bahwa iri hati memprediksi Schadenfreude diiringi atau tanpa diiringi perasaan bermusuhan, serta menunjukkan bahwa hasil yang bertentangan dari penelitian sebelumnya tidak dapat dikaitkan dengan dimasukkan atau tidaknya 
perasaan bermusuhan dalam assesmen iri hati (assessment of envy). Baik perasaan iri hati maupun permusuhan memiliki kontribusi masingmasing untuk pengalaman Schadenfreude. Temuan saat ini juga menunjukkan bahwa iri hati memprediksi Schadenfreude ketika peserta mempelajari kemalangan dari target gender yang sama, sedangkan iri hati tidak memprediksi Schadenfreude ketika peserta mempelajari kemalangan dari target gender yang berbeda. Hasil ini menunjukkan bahwa iri hati memprediksi Schadenfreude ketika ada kesamaan antara target Schadenfreude dan orang yang iri.

Chesler (2009) yang menyatakan bahwa kedengkian yang dimiliki sesama jenis lebih kuat dibanding lawan jenis, karena masing-masing bersaing untuk memperebutkan posisi yang sama. Berdasarkan teori perbandingan sosial, bahwa kedengkian muncul dari pembandingan sesaam jenis, misal kita sama-sama perempuan atau laki-laki tapi dia lebih beruntung dari aku, kedengkian ini memicu schadenfreud (kesenangan yang tidak lazim atas kemalangan atau ketidak beruntungan yang menimpa orang lain), schadenfreud mumcul untuk mengurangi intensitas kedengkian atau iri hati.

Secara umum, keputusan untuk bersaing ditentukan oleh Self Esteem dan secara khusus ditentukan oleh evaluasi kemampuan diri. Semakin orang yakin dengan kemampuan dirinya maka semakin dia terlibat dalam persaingan dengan orang lain. Perempuan menggunakan gosip dalam rangka mengalahkan rival dan sebagai bentuk kedengkian, karena gosip merupakan kekuatan dan senjata yang paling ampuh dalam menggagalkan dan menyabotase potensi orang lain dan memutus hubungan dan komunikasi sosial.

Konsensus di antara parapeneliti di bidang ini yang dapat diharapkan mengenai pernyataan bahwa iri hati, dalam arti paling 
umum, adalah rasa sakit pada nasib baik orang lain, seperti yang telah didefinisikan Aristoteles. Namun, dari titik konsensus ini, definisi berbeda. Beberapa definisi menekankan komponen yang bermusuhan (Miceli \& Castelfranchi, 2007; Parrot \& Smith, 1993) sedangkan yang lain berpendapat bahwa hanya mengingini yang dimiliki orang lain sudah masuk kategori iri hati (Hareli \& Weiner, 2002; Leach \& Spears, 2008). Yang lain berargumen bahwa iri hati dapat menyatu dengan emosi lain, sehingga membentuk pengalaman yang berbeda (misalnya, Feather et al., 2013). Pandangan peneliti adalah bahwa rasa iri hati pada tingkat terluas adalah rasa sakit atas nasib baik orang lain. Tetapi jika istilah diperluas, peneliti berpikir untuk membuat perbedaan antara dua jenis iri hati, yaitu iri hati negatif (malicious envy/hasud) dan iri hati positif (benign envy/ghibthoh), sehingga dapat membantu untuk memahami perilaku iri hati yang cenderung melakukan perbandingan sosial ke atas (upward social comparison). Menggunakan perbedaan ini memungkinkan peneliti untuk membentuk hipotesis baru dan mengujinya. Tentu saja, ini tergantung pada bagaimana iri hati dioperasionalkan. Iri hati dapat digunakan untuk merujuk pada iri hati umum, sebuah iri hati yang didefinisikan sebagai kedengkian ditambah keinginan dan niat buruk terhadap yang lain. Dalam literatur saat ini, iri hati hati digunakan untuk merujuk pada ketiga operasionalisasi ini. peneliti percaya bahwa membuat eksplisit bagaimana seseorang melihat iri hati (terlepas apakah itu digambarkan sebagai tipe iri hati (benign and malicious), campuran atau kecemburuan yang diikuti motivasi terpisah) akan membantu lebih jauh pemahaman tentang bagaimana orang berperilaku setelah melakukan perbandingan sosial ke atas (upward social comparison) yang menyakitkan. 
Aufa Abdillah

Temuan kami menambah bukti yang sudah substansial yang mengaitkan rasa kelayakan atau kepantasan dengan Schadenfreude: keuntungan yang tidak pantas menyebabkan lebih banyak Schadenfreude (Feather \& Nairn, 2005; Van Dijk et al., 2009). Selain itu, bahwa kemarahan (atau dendam) menyebabkan Schadenfreude (mis., Feather \& Sherman, 2002).

\section{Simpulan}

Temuan saat ini menunjukkan bahwa iri hati memprediksi Schadenfreude diiringi atau tanpa diiringi perasaan bermusuhan, serta menunjukkan bahwa hasil yang bertentangan dari penelitian sebelumnya tidak dapat dikaitkan dengan dimasukkan atau tidaknya perasaan bermusuhan dalam assesmen iri hati (assessment of envy). Baik perasaan iri hati maupun permusuhan memiliki kontribusi masingmasing untuk pengalaman Schadenfreude. Temuan saat ini juga menunjukkan bahwa iri hati memprediksi Schadenfreude ketika peserta mempelajari kemalangan dari target gender yang sama, sedangkan iri hati tidak memprediksi Schadenfreude ketika peserta mempelajari kemalangan dari target gender yang berbeda. Hasil ini menunjukkan bahwa iri hati memprediksi Schadenfreude ketika ada kesamaan antara target Schadenfreude dan orang yang iri.

Hasil penelitian ini menunjukkan bahwa temuan sebelumnya mengenai peran iri hati dalam Schadenfreude tidak bertentangan, tetapi lebih bersifat pelengkap. Temuan-temuan awal ini telah menunjuk pada keadaan tertentu di mana iri hati itu dan bukan merupakan prediktor Schadenfreude. Studi Smith et al. (1996) dan Brigham et al. (1997) mengemukakan bahwa iri hati memprediksi Schadenfreude seseorang jika ketidakberuntungan menimpa seseorang yang serupa dan mungkin 
Aufa Abdillah

berfungsi sebagai perbandingan sosial yang relevan. Studi Feather dan Sherman (2002) serta Hareli dan Weiner (2002) mengemukakan bahwa iri hati tidak memprediksi Schadenfreude seseorang jika suatu kemalangan menimpa seseorang yang kurang serupa dan karenanya cenderung menjadi pembanding sosial yang relevan. Secara bersamasama, temuan sebelumnya dan sekarang menunjukkan bahwa Schadenfreude adalah kondisi emosi sebagai respon psikologis multipenentuan, yang dapat ditimbulkan oleh perasaan permusuhan dan rasa iri hati. Kedua reaksi emosi psikologi ini mungkin tidak diperlukan untuk memunculkan Schadenfreude, tetapi mereka mungkin cukup untuk mendapatkan kepuasan dan kesenangan pada kemalangan orang lain.

\section{DaftarPustaka}

Aiken, L. S., \& West, S. G. (1991). Multiple regression: Testing and interpreting interactions. London: Sage Ltd.

Ben-Ze'ev, A. (2000). The subtlety of emotions. Cambridge, MA: MIT Press. Brigham, N. L., Kelso, K. A., Jackson, M. A., \& Smith, R. H. (1997). The roles of invidious comparisons and deservingness in sympathy and Schadenfreude. Basic and Applied Social Psychology, 19, 363-380.

Chesler, P. (2009). Woman's Inhumanity to Woman. Chicago: Lawrence Hill Books.

Crusius, J., \& Mussweiler, T. (2012). When people want what others have: The impulsive side of envious desire. Emotion, 12, 142-153.

Eisenberg, N. (2000). Empathy and Sympathy. In M. Lewis \& J. HavilandJones (Eds.), Handbook of emotions (pp. 677-691). New York: Guilford Press.

Elster, J. 1989. The cement of society. New York: Cambridge University Press. 
Feather, N. T. (1989). Attitudes towards the high achiever: The fall of the tall poppy. Australian Journal of Psychology, 41, 239-267.

Feather, N. T. (1994). Attitudes towards high achievers and reactions to their fall: Theory and research concerning tall poppies. Advances in Experimental Social Psychology, 26, 1-73.

Feather, N. T., \& Nairn, K. (2005). Resentment, envy, Schadenfreude, and sympathy: Effects of own and other's deserved or undeserved status. Australian Journal of Psychology, 57, 87-102.

Feather, N. T., \& Sherman, R. (2002). Envy, resentment, Schadenfreude, and sympathy: Reactions to deserved and undeserved achievement and subsequent failure. Personality and Social Psychology Bulletin, 28, 953-961.

Feather, N. T., Wenzel, M., \& McKee, I. R. (2013). Integrating multiple perspectives on Schadenfreude: The role of deservingness and emotions. Motivation and Emotion, 37, 575-585.

Fiske, S. T. (2011). Envy up, scorn down: How status divides us. New York, NY: Russell Sage.

Gastorf, J. W., \& Suls, J. (1978). Performance evaluation via social comparison: Performance similarity versus related-attribute similarity. Social Psychology, 41(4), 297-305. https://doi.org/10.2307/3033582

Goethals, G. R., \& Darley, J. (1977). Social c omparison theory: An attributional approach. In J. Suls \& R. L. Miller (Eds.), Social comparison processes: Theoretical and empirical perspectives (pp. 259-278). Washington, DC: Hemisphere.

Hareli, S., \& Weiner, B. (2002). Dislike and envy as antecedents of pleasure at another's misfortune. Motivation and Emotion, 26, (4), 257-277. https://doi.org/10.1023/A:1022818803399 
Heider, F. (1958). The psychology of interpersonal relations. New York: Wiley.

Leach, C. W., Spears, R., Branscombe, N. R., \& Doosje, B. (2003). Malicious pleasure: Schadenfreude at the suffering of another group. Journal of Personality and Social Psychology, 84(5), 932-943. https://doi.org/10.1037/0022-3514.84.5.932

Lockwood, P., \& Kunda, Z. (1997). Superstars and me: Predicting the impact of role models on the self. Journal of Personality and Social Psychology, 73, (1), 91-103. https://doi.org/10.1037/00223514.73.1.91

Major, B. (1994). From social inequality to personal entitlement: The role of social comparisons, legitimacy appraisals, and group membership. In M. Zanna (Ed.), Advances in Experimental Social Psychology, 26, 293-355). New York: Academic Press.

Major, B., Testa, M., \& Bylsma, W. H. (1991). Responses to upward and downward comparisons: The impact of esteem-relevance and perceived control. In J. Suls \& T. A. Wills (Eds.), Social comparison: Contemporary theory and research (pp. 237-260). Hillsdale, NJ: Erlbaum.

Miceli, M., \& Castelfranchi, C. (2007). The envious mind. Cognition and $\begin{array}{lll}\text { Emotion, 21, 449-479. } & \text { (3), }\end{array}$ https://doi.org/10.1080/02699930600814735

Miller, D. T., Downs, J. S., \& Prentice, D. A. (1998). Minimal conditions for the creation of a unit relationship: The social bond between birthdaymates. European Journal of Social Psychology, 28, (3), 475481. https://doi.org/10.1002/(SICI)10990992(199805/06)28:3<475::AID-EJSP881>3.0.CO;2-M 
Miller, D. T., Turnbull, W., \& McFarland, C. (1988). Particularistic and universalistic evaluation in the social comparison process. Journal of Personality and Social Psychology, 55, (6), 908-917. https://doi.org/10.1037/0022-3514.55.6.908

Mora, R. (1987). Egalitarian envy. New York: Paragon.

Ortony, A., Clore, G. L., \& Collins, A. (1988). The cognitive structure of emotions. New York: Cambridge University Press.

Parrott, W. G. (1991). The emotional experience of envy and jealousy. In P. Salovey (Ed.), The psychology of jealousy and envy (p. 3-30). Guilford Press.

Parrott, W. G., \& Smith, R. H. (1993). Distinguishing the experiences of envy and jealousy. Journal of Personality and Social Psychology, 64, (6), 906-920. https://doi.org/10.1037/0022-3514.64.6.906

Plato. (1925). Plato (H. N. Fowler \& W. R. M. Lamb, Trans). New York: Putnam. (Original work published 427-348 B. C.)

Schaubroeck, J., \& Lam, S. S. K. (2004). Comparing lots before and after: Promotion rejectees' invidious reactions to promotees. Organizational Behavior and Human Decision Processes, 94, (1), 33-47. https://doi.org/10.1016/j.obhdp.2004.01.001

Smith, R. H. (1991). Envy and the sense of injustice. In P. Salovey (Ed.), The psychology of jealousy and envy. New York: Guilford Press.

Smith, R. H. (2000). Assimilative and contrastive emotional reactions to upward and downward social comparison. In J. Suls \& L. Wheeler (Eds.), Handbook of social comparison: Theory and research. New York: Kluwer Academic/Plenum Press Publishers.

Smith, R. H., Turner, T. J., Garonzik, R., Leach, C. W., Urch-Druskat, V., \& Weston, C. M. (1996). Envy and Schadenfreude. Personality and 
Social Psychology Bulletin, 22, (2), 158-168. <http://hdl.handle.net/2027.42/69046>

Spinoza, B. (2002). Ethica (H. Krop, Trans). Amsterdam: Prometheus/ Bert Bakker. Original work published 1677.

Tesser, A. (1991). Emotion in social comparison and reflection processes. InJ.Suls \& T.A. Wills (Eds.), Social comparison: Contemporary theory and research, 115-145). Hillsdale, NJ: Erlbaum.

Tesser, A., Millar, M., \& Moore, J. (1988). Some affective consequences of social comparison and reflection processes: The pain and plasure of being close. Journal of Social and Personality Psychology, 54, (1), 49-61. DO - 10.1037//0022-3514.54.1.49

Van de Ven, N., Zeelenberg, M., \& Pieters, R. (2012). Appraisal patterns of envy and related emotions. Motivation and Emotion, 36, (2), 195204. doi: 10.1007/s11031-011-9235-8

Van Dijk, W. W., Ouwerkerk, J. W., Goslinga, S., \& Nieweg, M. (2005). Deservingness and Schadenfreude. Cognition and Emotion, 19, (6), 933-939. https://doi.org/10.1080/02699930541000066

Wood, J. V. (1989). Theory and research concerning social comparison of personal attributes. Psychological Bulletin, 106, (2), 231-248. http://www.communicationcache.com/uploads/1/0/8/8/108872 48/theory_and_research_concerning_social_comparisons_of_perso nal_attributes.pdf 